\title{
Concepts of Sustainable Development; a Literature Review and a Systematic Framework for Connecting the Role of Education with the Sustainable Development Goals (SDGs).
}

\author{
Patricia Ikouta Mazza* \\ Quantitative Methods Laboratory Department of Business Administration, University of the Aegean 8 Michalon \\ Street, P.S. 82100 Chios, Greece
}

\begin{abstract}
*Corresponding Author: Patricia Ikouta Mazza, Quantitative Methods Laboratory Department of Business Administration, University of the Aegean 8 Michalon Street, P.S. 82100 Chios, Greece
\end{abstract}

\begin{abstract}
Sustainable development has been in the center of interest both in academic literature and in various countries' national development plans. The concept of sustainable development arises from a new worldview, which believes that survival, continued progress, and maintenance of the human community depends on the continued health and viability of the earth's life support systems. The most essential point to sustainable development is the realization that economic growth alone is not enough to solve the world's problems: economic, social, and environmental aspects of any action are interconnected. Considering only one of these at a time, leads to errors in judgment and "unsustainable" outcomes. Focusing only on profit margins, for example, has historically led to social and environmental damages that cost society in the long run. Sustainable Development grew from numerous environmental movements and non-governmental organizations, in earlier decades, and was defined in 1987 by the World Commission on Environment and Development (Brundtland Commission 1987). The 2030 Agenda for Sustainable Development was adopted at the 70th General Assembly of the United Nations, in 2015 and sets 17 Sustainable Development Goals (SDGs).One of these goals, SDG 4is the education goal, and it aims to "ensure inclusive and equitable quality education and promote lifelong learning opportunities for all." This paper reviews the conceptual history of 'sustainable development', from 1987 up today. The goal of this study is to propose a framework for understanding the dimensions of sustainable development and to provide a framework for connecting the role of Education with the SDGs of Agenda 2030.
\end{abstract}

Keywords: Agenda 2030, Education for Sustainable Development, Sustainable development, Sustainability.

\section{INTRODUCTION}

The concept of sustainability is based on classical economists. The idea of sustainable development was already present in the debate on narrowness and enlargement. Malthus, Ricardo, Mill, Hicks, Pigou, and many others had predicted that the lack of natural resources would lead to a slowdown and eventual cessation of economic growth. (Meadows, D., and Randers, J., 1992, Mebratu, D., 1998). Sustainable development refers to the development (economic, social \& environmental) that is planned and implemented considering the protection of the environment and sustainability.

The first major milestone in establishing the importance of the environment on a global scale was the 1972 UN Environment Summit in Stockholm(United Nations,1983). This Summit, in addition to the adoption of the policy Declaration and Action Plan, led to the establishment of the UN Environment Program. Fifteen years after the Stockholm Summit in 1987, the Minister of the Environment of Norway, Mrs. Brundtland set up the eponymous special committee to look at the issue of development and its impact on the environment. The Brundtland Commission has published a report entitled "Our Common Future", which for the first time defined: sustainable development as the development that meets the needs of today's generation without limiting the ability to meet the needs of future generations (Brundtland Commission, 1987). This report linked environmental protection for the first time to the issue of economic development and social well-being and prosperity and began consolidating sustainable development.In 1992, twenty years after the Stockholm Summit, the UN held its World Conference on Environment and Development in Rio de Janeiro, Brazil (United Nations, 1993, Drexhage, J., and Murphy, D., 2010). The main result of Rio was the preparation of a 
Report, known as "Agenda 21", which refers to the obligations and goals of the International Community to achieve a better life and the goals of sustainability for the 21st century.Agenda 21 includes 40 chapters that cover all issues related to the triptych Economy-Society-Environment, from the fight against poverty to the issues of development cooperation and the need to create appropriate institutions.In 2002, the World Conference on Sustainable Development was held in Johannesburg, South Africa, culminating in the Stockholm Conference in 1972 and the Rio Conference in 1992 (United Nations, 2003). Both conferences were very important. The first stressed the importance of the environment and the second affirmed the relationship between environmental protection and economic and social development.

The European Union (EU) is approaching sustainable development through two strategies:

(a) Europe 2020 Strategy

(b) Agenda 2030

"Europe 2020"strategy aims to coordinate social and economic policy, based on Smart, Sustainable and Inclusive Growth(European Commission, 2010). Strategy 2020 "summarizes the European model of the Social Economy with a strong environmental dimension. Europe 2020 seeks to achieve: Smart growth, through the promotion and enhancement of knowledge, research, and innovation as drivers of our future growth. Sustainable development, through the promotion of a greener and more competitive economy, with the right use of resources in efficiency. Without Exclusion of growth through the promotion of an economy with high employment rates that will achieve social and territorial cohesion.

The 2030 Agenda for Sustainable Development was adopted at the 70th General Assembly of the United Nations, in 2015, with the Resolution "Transforming Our World: The 2030 Agenda for Sustainable Development" (United Nations,A/RES/70/1, 2015). Agenda 2030 is the most ambitious global agreement the UN has ever reached, as it is an action plan for People, the Planet and Prosperity. Agenda 2030 promotes the integration of all three dimensions of sustainable development - social, environmental, and economic - into all sectoral policies, while promoting interconnection and the coherence of policy and legislative frameworks related to the Sustainable Development Goals (SDGs). Agenda 2030 is an action plan for People, the Planet and Prosperity, which seeks to strengthen world Peace and implement it through the Partnership of all countries and stakeholders. These five thematic objectives ("5 Ps") constitute the core of the "Agenda 2030". The "Agenda 2030" sets 17 Sustainable Development Goals (SDGs) and 169 targets and the purpose is to eradicate poverty and achieve sustainable development on a global scale by 2030 , with no one left on the sidelines. These are specific goals for the next 15 years, which focus on human dignity, regional and global stability, ensuring the "health" of our planet, just and resilient societies and prosperous economies. They are global and general implementation goals with an implementation schedule until 2030. They create implementation commitments for all countries, developed and developing, considering the different national realities, levels of development, national policies, and priorities (European Commission, 2015).

\section{The Key Role Of Education In The Sustainable Development Goals}

Education as a factor in achieving sustainable development highlighted in the Europe 2020 strategy(European Commission, 2010, UNESCO, 2019). The Europe 2020 strategy set two targets regarding the Education area: i) reducing the number of early school leavers and ii) increasing the share of young adults who have completed tertiary education (European Commission, 2010).Particularly, the EU has set a target of reducing early leavers of education and training to less than 10 percent of population aged 18 to 24 and increasing the tertiary educational attainment to 40 percent of the same age frame.

As we said in the above section, Europe 2020 aims to achieve Smart, Sustainable and Inclusive Growthto overcome the structural weaknesses in Europe's economy, improve its competitiveness and productivity. To reach these goals the EU has adopted various targets to achieve by 2020 in five areas: employment, $\mathrm{R} \& \mathrm{D}$, climate change and energy, education, and poverty reduction. With the adoption of the Europe 2020 strategy, the first results have begun to appear. Early leaving from education and training has been falling continuously in the EU since 2002, for both men and women. The fall from 
17.0 percent in 2002 to 10.6 percent in 2017 represents steady progress towards the Europe 2020 target of 10 percent, (United Nations Report, 2018).

The situation seems to be similar in the target to increasing attainment at tertiary level for 30- to 34year-olds, given the fact that the percentage of people who have attained tertiary education in the EU28 reached 39.9 percent in 2017, which is just 0.1 percentage point short of its Europe 2020 target.Between 2002 and 2017, the share of 30- to 34-year-old having completed tertiary education grew continuously from 23.6 percent to 39.9 percent(United Nations Report, 2018).

"Education and training play an important role in improving employability," according to the Europe 2020 report, "The employment rate of recent graduates (20- to 34-year-olds having left education and training in the past one to three years) has dropped considerably due to the economic and financial crisis. It fell from 82.1 percent in 2008 to 75.4 percent in 2013. However, it has clearly increased since 2013, reaching 80.2 percent in 2017"(United Nations Report, 2018).

Great emphasis on the role of Education was also given in the Agenda 2030 as it is one of the 17 goals set for achieving sustainable development and sustainability(Agenda 2030, 2015). Ambitions for education are essentially captured in Sustainable Development Goal 4 (SDG 4) of the 2030 Agenda which aims to "ensure inclusive and equitable quality education and promote lifelong learning opportunities for all" by 2030.

The SDG 4has seven associated 'targets' at the global level that are universally applicable (and three targets which are so called 'means of implementation') (Agenda 2030, 2015):

1. Ensure universal, free, equitable, and quality primary and secondary education.

2. Ensure universal access to quality pre-primary education.

3. Ensure equal access to quality technical, vocational, and tertiary education.

4. Increase the number of youth and adults who have relevant skills, including technical and vocational skills, for employment, decent jobs and entrepreneurship.

5. Ensure equal access to all levels of education particularly of marginalised groups.

6. Achieve full literacy of youths and substantially increase literacy of adults.

7. Ensure that all learners acquire the knowledge and skills needed to promote sustainable development, including, among others, through education for sustainable development and sustainable lifestyles, human rights, gender equality, promotion of a culture of peace and nonviolence, global citizenship and appreciation of cultural diversity and of culture's contribution to sustainable development.

Means of implementation:

1. Build and upgrade education facilities that are child, disability and gender sensitive and provide safe, nonviolent, inclusive, and effective learning environments for all.

2. Substantially expand globally the number of scholarships available to developing countries, least developed countries, small island developing States and African countries, for enrolment in higher education, including vocational training and information and communications technology, technical, engineering and scientific programmes, in developed countries and other developing countries.

3. Substantially increase the supply of qualified teachers, including through international cooperation for teacher training in developing countries, especially least developed countries and small island developing states.

In summary we can say that quality education is the foundation of sustainable development because it: facilitates the lifting of people out of poverty and prevents the perpetuation of poverty from generation to generation

$\checkmark$ empowers marginalized groups

$\checkmark$ enables the realization of other human rights 
Concepts of Sustainable Development; a Literature Review and a Systematic Framework for Connecting the Role of Education with the Sustainable Development Goals (SDGs).

$\checkmark$ reduces social, economic, and power inequality

$\checkmark$ drives sustainable and inclusive economic growth

$\checkmark$ facilitates peace, tolerance, and respect for human rights

Equally, the right to education cannot be fully realized without sustainable development because poverty - as well as being unjust, unnecessary, and a human rights violation - is one of the biggest barriers to access to education(Agenda 2030, 2015).

\section{A CONCEPTUal Framework Of Sustainability}

In this section we are trying to define parameters or factors which could influence the concept of sustainable development (United Nations, 2008, Boggia, A., Cortina, C. 2010). As mentioned at introduction a numerous of factors affect each one of the three dimensions, environmental, economic, and social of sustainable development. The proposed framework has two phases. At Phase I we are trying to define factors based on literature which influence the three dimensions of sustainable development, while at Phase II we determine which of these factors accelerate and which of them slow down the sustainability.

The following table presents several factors as used for calculating International Indices Frameworks such as(Bossel, H., 1999):

- Human Development Index, (HDI) by UNDP (1990)

- Ecological Footprint (EF) by Wackernagel and Rees (1996),

- Index of Sustainable Economic Welfare (ISEW) by Daly et Cobb (1989),

- Genuine Progress Indicator by Cobb et al (1995),

- Environmental Performance Index a óó

Table1. Factorial Variables for each Dimension

\begin{tabular}{|c|c|c|}
\hline Economic & Social & Environmental \\
\hline Trade balance: exports of goods & Populationgrowth & Production of crudeoil \\
\hline Valueadded in agriculture & Population & Totalprimaryenergysupply \\
\hline Value financial sector & $\begin{array}{l}\text { Number of teachers in Special } \\
\text { Education }\end{array}$ & Totalprimaryenergydemand \\
\hline Householdincome & $\begin{array}{llll}\begin{array}{l}\text { Number of schools per } \\
\text { kilometer }\end{array} & \text { square } \\
\end{array}$ & Contribution of renewableenergy \\
\hline $\begin{array}{l}\text { Actual Value added in } \\
\text { agriculture }\end{array}$ & $\begin{array}{l}\text { Number of hospitals per square } \\
\text { kilometer }\end{array}$ & Totalenergyproduction \\
\hline GDP Growth & $\begin{array}{l}\text { Number of points Disabled access to } \\
\text { road }\end{array}$ & Totalprimaryenergysupply \\
\hline Unemployment Rate & $\begin{array}{l}\text { Number of services offered to people } \\
\text { with disabilities }\end{array}$ & Electricitygeneration \\
\hline Valueadded in construction & & $\begin{array}{l}\text { Landings of fish in the domestic } \\
\text { market }\end{array}$ \\
\hline Valueadded in industry & & $\begin{array}{llll}\mathrm{CO} 2 & \text { emissions } & \text { from } & \text { fuel } \\
\text { combustion } & & & \\
\end{array}$ \\
\hline Imports of services & & Aquaculture \\
\hline Exports of goods & & $\begin{array}{l}\text { Number of broadband connections } \\
\text { per } 100000 \text { inhabitants }\end{array}$ \\
\hline Imports of goods & & $\begin{array}{l}\text { Number of optical fibers per } 1 \\
\text { square kilometer }\end{array}$ \\
\hline \multicolumn{3}{|l|}{ exports of goods } \\
\hline \multicolumn{3}{|l|}{ Value added in other services } \\
\hline \multicolumn{3}{|l|}{ Exports of services } \\
\hline \multicolumn{3}{|l|}{ Self-employment rates } \\
\hline \multicolumn{3}{|l|}{ GrossDomesticProduct } \\
\hline \multicolumn{3}{|l|}{ Gross and Net National Income } \\
\hline \multicolumn{3}{|l|}{$\begin{array}{llll}\text { Gross } & \text { National } \\
\text { capita } & & & \\
\end{array}$} \\
\hline Per capita GDP & & \\
\hline
\end{tabular}



the Role of Education with the Sustainable Development Goals (SDGs).

At Phase II we define which of the above factors improve the sustainability. More specifically, we present at xy- cartesian system the contribution of each of the variables, named at Table 1 , to each dimension of the sustainability. In other words, yy' axis represents the examined dimension: economic, social and environmental and $\mathrm{xx}^{\prime}$ axis represents the contribution of each variable at the examined dimension.

Variables, which are positioned at zero point, the point where the two axes are crossed, do not improve the dimension of the sustainability, which is under examination. Variables that are positioned at the $1^{\text {st }}$ quartile improve the examined dimension. The higher their position, the major their contribution. Variables that are positioned at the $2^{\text {nd }}$ quartile have positive contribution, while variables at $3^{\text {rd }} \& 4^{\text {th }}$ quartile have negative contribution

Figures 3, 4 and 5 present the contribution of the variables listed at Table 1 at economic, social, and environmental dimension respectively. We must note here that the position of the variables at the Cartesian system is made based on authors' ideas and believes.

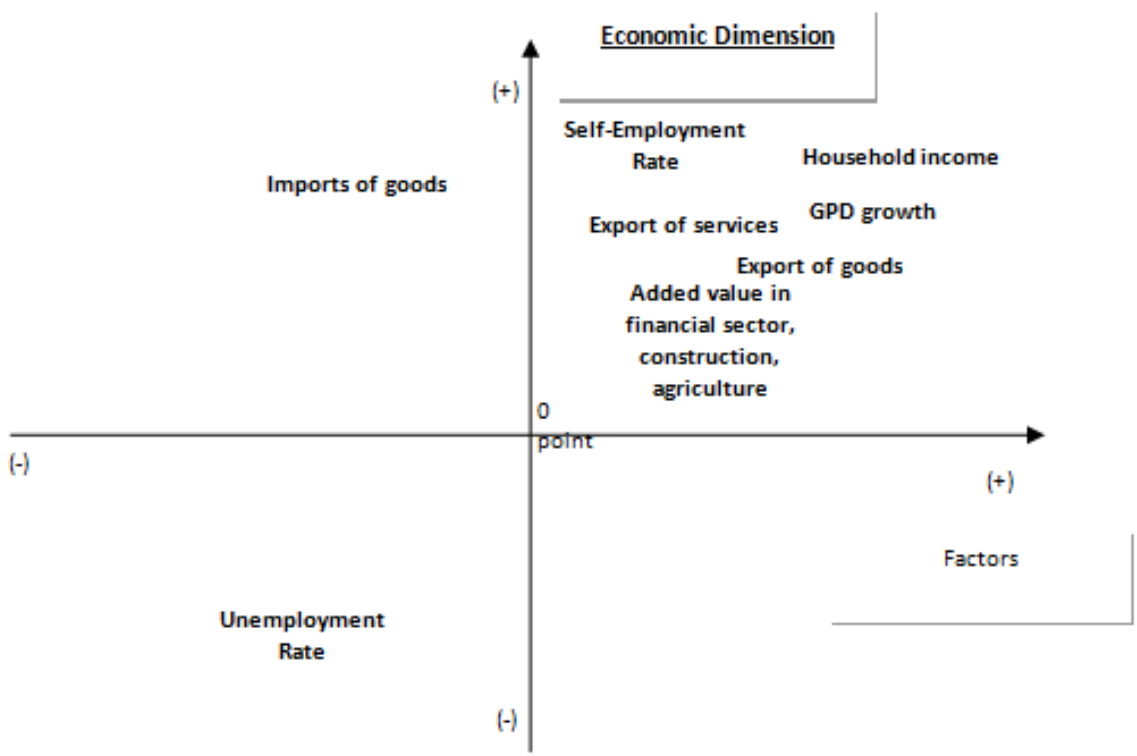

Figure3. Factors influence economic dimension

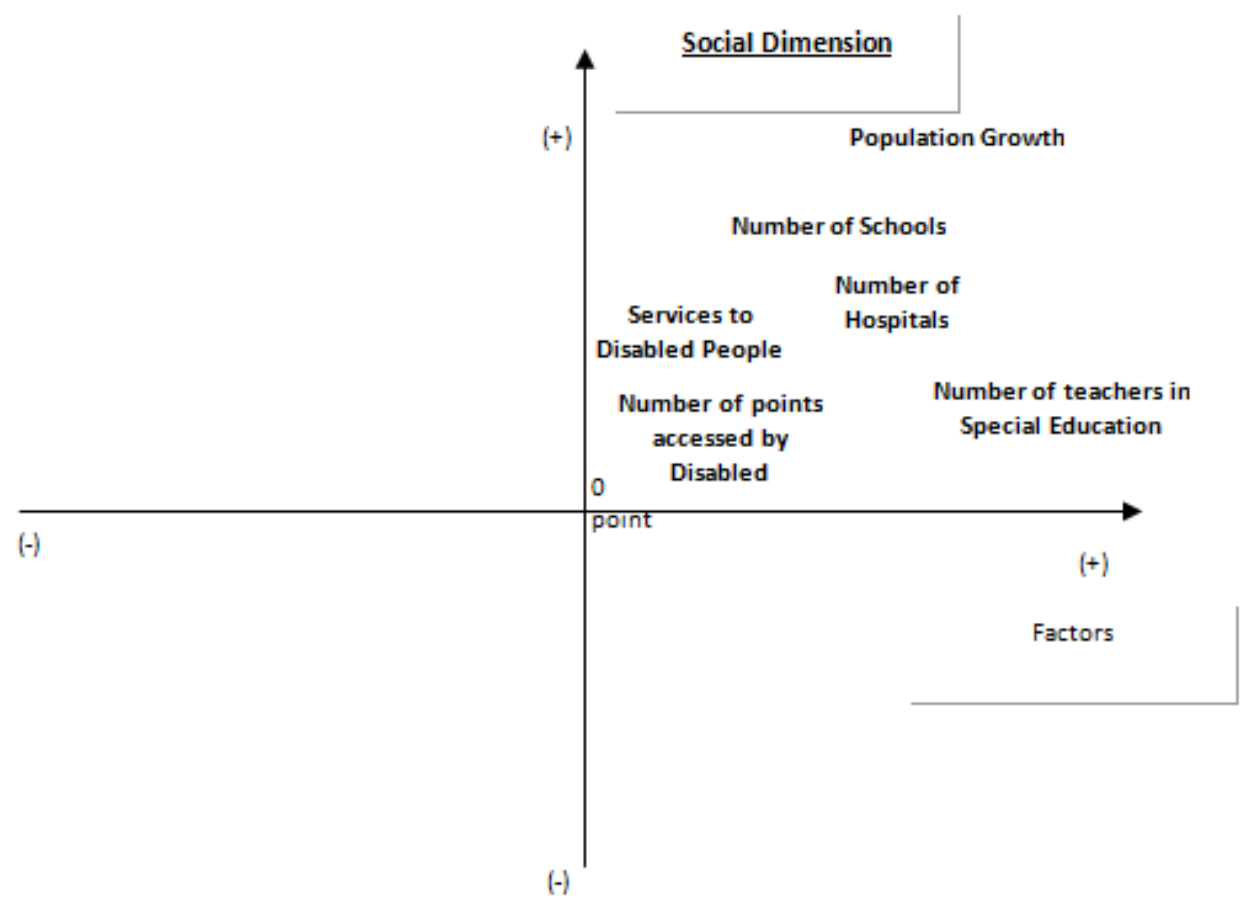

Figure4. Factors influence social dimension 


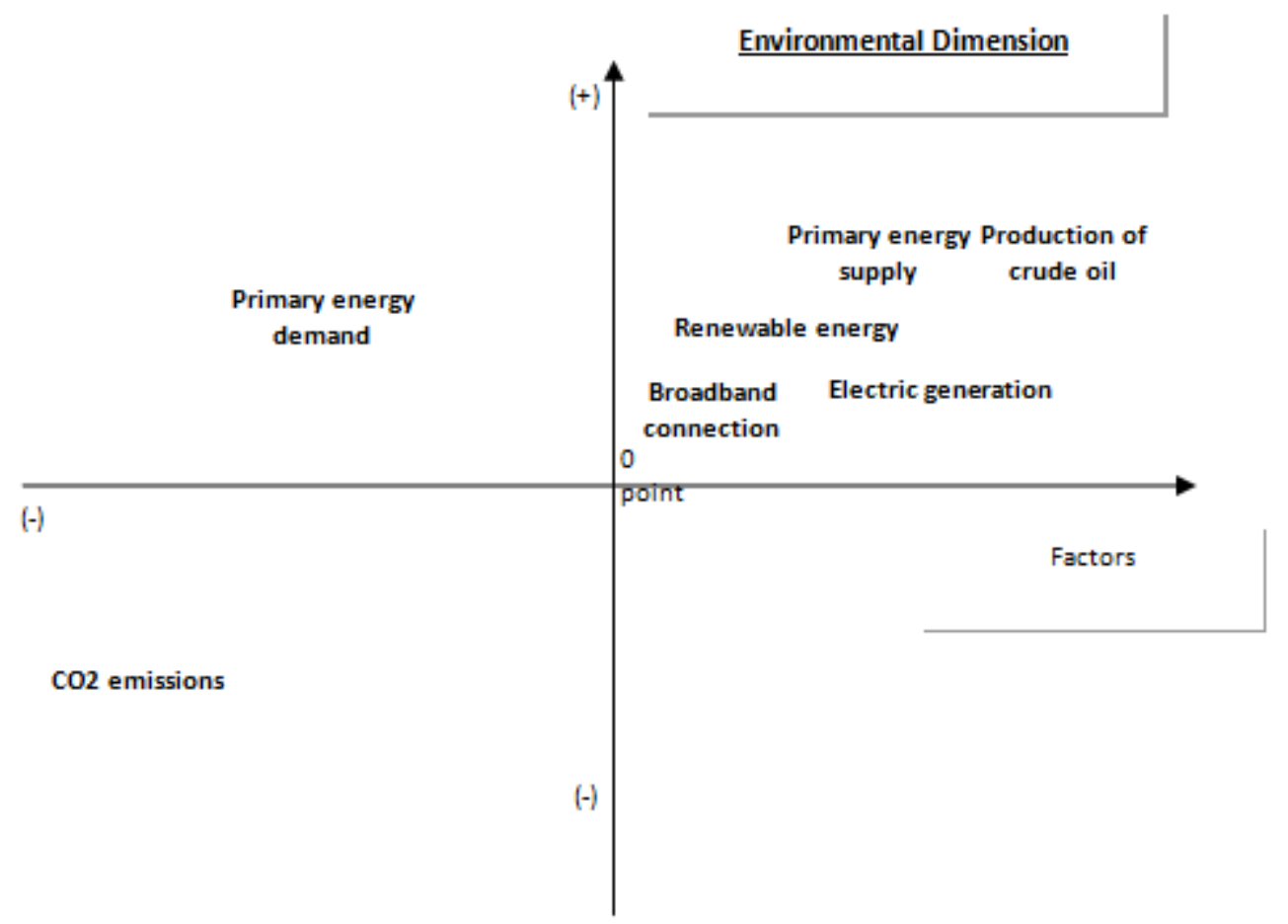

Figure5. Factors influence Environmental dimension

As can be seen from the above diagrams, Education is one of the key factors influencing the second dimension of sustainable development, the social dimension. As shown in Figure 2, education has a positive contribution to improving the sustainable development of an area and is in a high position in relation to the factors that determine the social dimension of sustainability.

\section{CONClusion}

Sustainable development refers to the ability of our societies to meet the needs of the present without sacrificing the ability of future generations to meet their own needs. It is undeniable that the concept of "sustainable development" received higher currency and prominence after the publication of the report of WCED (1987), Our Common Future. Nevertheless, the earlier attempt of developing the "theory of environmental limits" by Thomas Malthus and David Ricardo. It is generally accepted that sustainable development calls for a convergence between the three pillars of economic development, social equity, and environmental protection.

In this paper we examine the role that Education plays in achieving sustainable development which was highlighted in all the strategies at European level and at the level of the United Nations, and we see that has a positive contribution to improving the sustainable development. Education for Sustainable Development is a lifelong learning process and an integral part of quality education. It enhances the cognitive, social and emotional and behavioral dimensions of learning. It is holistic and transformational, and encompasses learning content and outcomes, pedagogy and the learning environment itself.The first part of this paper reviews the conceptual history of 'sustainable development', from the Brundtland Commission's definition in 1987 to the present day. A conceptual framework for estimating the contribution of dimension to sustainability is also proposed in this study. A numerous of variables which influence each dimension of the sustainability were identified and a representation of their contribution in each dimension was developed in a xy-cartesian system. To transform the proposed framework to a decision tool, which could help authorities to make decisions several steps are necessary. Identify more variables from literature, develop a measurement tool, which defines the added value of each variable to each dimension, and finally propose a mathematical model, which measures the sustainability.

\section{REFERENCES}

[1] Brundtland Commission, "Our Common Future: The World Commission on Environment and Development”. Oxford University Press, Oxford, (1987). 
Concepts of Sustainable Development; a Literature Review and a Systematic Framework for Connecting the Role of Education with the Sustainable Development Goals (SDGs).

[2] Meadows, D., and Randers, J. "Beyond the Limits”, London: Earthscan Publications, 1992.

[3] Mebratu, D., "Sustainability and Sustainable Development: Historical and Conceptual Review", International Institute for Industrial Environmental Economics, Lund University, (1998), pp. 6-11.

[4] United Nations, General Assembly, "Report of the World Commission on Environment and Development: Our Common Future”, United Nations, N. York.(1983).

[5] United Nations (1993), "Report of the United Nations Conference on the Environment and Development", United Nations, N. York.

[6] Drexhage, J., and Murphy, D., “Sustainable Development: From Brundtland to Rio 2012”,International Institute for Sustainable Development (IISD) New York, pp. 7-9, 2010.

[7] United Nations (2003), "World Summit on Sustainable Development Johannesburg 2002. Political Declaration and Plan of Implementation", United Nations, N. York.

[8] European Commission, "Europe 2020: A strategy for smart, sustainable and inclusive growth”, Brussels, 2010.

[9] United Nations, “Transforming our world: the 2030 Agenda for Sustainable Development”,A/RES/70/1, 2015.

[10] UNESCO, "Framework for the implementation of Education for Sustainable Development (ESD) beyond 2019”, General Conference 40 ${ }^{\text {th }}, 2019$.

[11] United Nations, “The Sustainable Development Goals Report”, 2018.

[12] United Nations (2008), "Measuring Sustainable Development", Report of the Joint UNECE/OECD/ Eurostat Working Group on Statistics for Sustainable Development.

[13] Boggia, A., Cortina, C. (2010). "Measuring sustainable development using a, multi-criteria model: A case study”, Journal of Environmental Management, 91, pp. 2301-2306.

[14] Bossel, H., (1999). “Indicators for Sustainable Development: Theory Methods, Applications”.

\section{AUTHOR'S BIOGRAPHY}

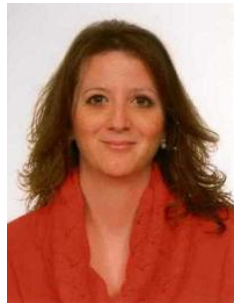

Patricia Ikouta Mazza, She was born in Sao Paolo, Brazil in 1983 and grew up in Rhodes, Greece. She graduated in June 2005 from the Department of Economic \& Regional Development of Panteion University of Social and Political Sciences. In the period 2005-2007 she attended the Postgraduate Program of the same department of Panteion University. Today she holds a PhD degree from the Department of Business Administration of the University of the Aegean and her research concerns on the "Development of models for measuring the sustainability of a region and comparative analysis of digital and physical regions".

Citation: Patricia Ikouta Mazza. "Concepts of Sustainable Development; a Literature Review and a Systematic Framework for Connecting the Role of Education with the Sustainable Development Goals (SDGs).” International Journal of Humanities Social Sciences and Education (IJHSSE), vol 8, no. 8, 2021, pp. 106-112. doi: https://doi.org/10.20431/2349-0381.0808009.

Copyright: (c) 2021 Authors. This is an open-access article distributed under the terms of the Creative Commons Attribution License, which permits unrestricted use, distribution, and reproduction in any medium, provided the original author and source are credited. 